\title{
Impact of Silkworm Excrement Organic Fertilizer on Hemp Biomass Yield and Composition
}

\author{
Małgorzata Łochyńska ${ }^{1 *}$, Jakub Frankowski² \\ 1 Department of Silkworms Breeding and Mulberry Cultivation, Institute of Natural Fibers and Medicinal Plants, \\ Wojska Polskiego 71B, 60-630 Poznań, Poland \\ 2 Department of Energy Crops Research, Institute of Natural Fibers and Medicinal Plants, Wojska Polskiego 71B, \\ 60-630 Poznań, Poland \\ * Corresponding author's e-mail: malgorzata.lochynska@iwnirz.pl
}

\begin{abstract}
The organic fertilization and ecological farming are becoming increasingly popular and required. The studies on the organic farming of hemp (Cannabis sativa L.) were presented in this article. One of the options of organic fertilizer is the mulberry silkworm (Bombyx mori L.) breeding waste. The breeding of this insect is a cheap source of waste which gives very positive results on the plants yield. In this research, 3 repetition pots were tested: with silkworm fertilizer $15 \mathrm{t} / \mathrm{ha}, 30 \mathrm{t} / \mathrm{ha}$ and pots without fertilization (control). The total length, technical length, panicles length and diameter of hemp were measured. Moreover, the chemical composition of plants with and without fertilization was compared. The mean total length and technical length were highest in 15t/ha of manure dose. In turn, the panicles and the diameter of hemp were highest after $30 \mathrm{t} /$ ha of manure dose.
\end{abstract}

Keywords: mulberry silkworm, Bombyx mori L., waste management, Cannabis sativa L.

\section{INTRODUCTION}

Due to the growing interest of consumers in the products from Cannabis sativa $\mathrm{L}$. other than fiber, the Institute of Natural Fibers and Medicinal Plants (INF\&MP) created a new hemp cultivar Henola, which is an oil type and different from the typical representatives of hemp grown for fiber. Compared with a typical fiber hemp variety Białobrzeskie, the new cultivar is characterized by a vegetation period shorter by about 3 weeks, height lower by half, significantly larger inflorescences and high yield of seeds over $40 \mathrm{dt} / \mathrm{ha}$ [Burczyk and Oleszak 2016].

The hemp straw remaining after harvesting seeds can be used in various branches of the economy, including for the production of biocomposites [Sawpan et al. 2011]. In addition, it can be employed for the energetic purposes [Rehman et al. 2013]. The energy value of Henola's straw is comparable with the parameters characterizing the typical fibrous hemp biomass grown both as a main crop and a catch crop, and amounts even to $19300 \mathrm{~kJ} / \mathrm{kg}$ of DM [Burczyk 2012].

Henola can also be grown to obtain other substances. The analyses showed that its inflorescences contain on average $0.32 \%$ of essential oils and $0.07 \%$ of CBD, which are increasingly often used in medicine [Gulluni et al. 2018, Mannucci et al. 2017]. Moreover, this cultivar is characterized by a very low content of THC $(0.013 \%)$, one of the psychoactive substances typical in Cannabis L. [Burczyk and Oleszak 2016, Colizzi and Murray 2018]. The cultivation of hemp for seeds or cannabinoids results in wasting the straw. Examining the amount and quality of produced hemp straw will help to determine its economic utilization.

Suitable agrotechnical methods to obtain the highest yield have to be examined for the Henola cultivar. An organic fertilization has not been studied in hemp cultivation so far. One of the options of cheap organic fertilizer involves the mulberry silkworm (Bombyx mori L.) excreta and breeding waste. Farmers may produce 
250-300 $\mathrm{kg}$ of waste from caterpillars breeding each year [Łochyńska and Frankowski 2018]. The silkworm excrement-derived organic fertilizer improves the yield and quality of crops and significantly amends the acidity and fertility of soil [Li et al. 2015, Chen et al. 2011]. Literature also reports that the excrements of silkworms increase the soil-available nutrients and organic matter content, soil enzyme activities in much greater quantities than the goat feces [Yang et al. 2016]. Moreover, this manure does not contain inhibitory compounds, detergents, antibiotics or antiseptics [Dobre et al. 2014]. Therefore, the studied material is an ecologically-friendly fertilizer which may be used in other bio-crops.

The aim of the present study was to test the influence of organic fertilization on the hemp biomass composition and yield with the use of silkworms breeding waste. The content of cellulose in straw was analyzed. The statistical analyses were used to determine the statistically significant differences between the mean scores of the unrelated groups.

\section{MATERIAL AND METHODS}

The Henola cultivar was obtained from the seeds material of Institute of Natural Fibres and Medicinal Plants (INF\&MP), Poznan, Poland. A pot experiment was conducted in three repetitions: in 2016 (R1), 2017 (R2) and 2018 (R3) inside vegetation hall in Experimental Farm of INF\&MP in Petkowo, Poland. The studies were prepared in May-September; thus, the conditions of cultivation and the photoperiod were similar. The manure of the mulberry silkworm was collected during the larvae breeding season in 2016 from the Department of Silkworms Breeding and Mulberry Cultivation INF\&MP. The feces of larvae were cylinder-shaped particles, $2-5 \mathrm{~mm}$ long, $1.5-5 \mathrm{~mm}$ in diameter. Dried manure was added and mixed with the soil from pots before hemp sowing.

The presented research contained pots with $15 \mathrm{t} /$ ha of silkworm fertilizer (18 $\mathrm{g}$ of manure/pot), $30 \mathrm{t} / \mathrm{ha}$ (36 $\mathrm{g}$ of manure/pot) and pots of hemp without fertilization, three replications of each. Every pot had a capacity 161 , diameter $0.3 \mathrm{~m}$, height $0.5 \mathrm{~m}$ and were filled with $20 \mathrm{~kg}$ of soil characterized by good water permeability and which was well-drained and aerated.
At the beginning of May, 10 seeds of hemp were sown in each pot. The best 8 plants in all pots were left after selection to next studies in order to keep the optimal sowing density. In the term between $25^{\text {th }}$ June and $1^{\text {st }}$ August, the plants flowered and were harvested at the beginning of September. The dried hemp ( $\mathrm{n}=24$ of each replication) was measured and total length, technical length, panicles length and diameter of hemp stalks were calculated.

The analyses of the chemical composition of the silkworm excreta were tested in the Chemical and Agricultural Station in Poznan, according to the following standards:

- PB.88 ed. 4/01.09.2010 for organic N,

- PB.29 ed. 7/13.042016 for $\mathrm{P}_{2} \mathrm{O}_{5}$,

- PB.30 ed. 7/13.04.2016 for $\mathrm{K}_{2} \mathrm{O}$ and $\mathrm{CaO}$,

- PB.31 ed 7/01.09.2010 for MgO,

- PB.92 ed. 3/01.09.2010 for $\mathrm{Cu}, \mathrm{Mn}, \mathrm{Zn}, \mathrm{Pb}$, $\mathrm{Cd}$.

The analyses of the chemical composition of the hemp biomass were performed at the Faculty of Wood Technology, the Poznan University of Life Sciences, Poland, according to the PN-92/P-50092 standard for plant material. The following parameters were determined:

- moisture content using the oven-dry (gravimetric) method,

- content of cellulose according to Seifert using a mixture of acetylacetone and dioxane,

- content of lignin according to Tappi using concentrated sulfuric acid,

- content of holocellulose using sodium chlorite,

- pentosanes using the trihydroxybenzene method,

- contents of minerals were determined according to the DIN 51731 standards.

The experimental materials were ground in a Pulverisette 15 laboratory mill, with the analytical fraction of $0.4-0.1 \mathrm{~mm}$ being separated on sieves.

The statistical analyses using the $\mathrm{R}$ software were performed by Metodolog Company in Gdynia, Poland. The one-way analysis of variance (ANOVA) was used to determine any statistically significant differences between the means of unrelated groups. The Pearson correlation test was used in order to confirm the existence of correlation between three different sets of cellulose and crop variables. The number of observation used for each analysis was identical $\mathrm{N}=9$, and only very strong relations were able to cross the significance threshold. 


\section{RESULTS AND DISCUSSION}

The biomass yield calculation and chemical composition analysis of the obtained material constituted the basis of the presented studies. The total length of hemp, technical length, panicles length and diameter in technical length were measured. The examination conducted in in three repetitions showed that the yield increases along with the level of fertilization (Tab. 1). Moreover, the length of panicles increases with the dose of fertilization.

The vegetation period in each year of the experiment and temperature conditions was similar; however, the longest period was recorded in the second year of the study (Tab. 2).

The chemical composition of silkworms manure showed that the material is comparable with the tests available in the literature (Tab. 3). It was shown that dry matter in excreta was $88.66 \%$ and total ash $23.33 \%$ [Farhat et al. 2015]. The silkworm waste is rich in nitrogen (36.2-46.8\%), calcium (0.58-3,91\%), phosphorus $(0.22-0.82 \%)$, and contain trace elements, such as $\mathrm{Cu}(8-12.5 \mathrm{mg} / \mathrm{kg}), \mathrm{Mn}(87.17 \mathrm{mg} / \mathrm{kg})$, $\mathrm{Fe}(1962-2560 \mathrm{mg} / \mathrm{kg}), \mathrm{Zn}(43.8 \mathrm{mg} / \mathrm{kg})$ and $\mathrm{Pb}$ $(5.93 \mathrm{mg} / \mathrm{kg})$ [Wang et al. 2016, Yaman 2016].

The chemical composition of hemp biomass has been analyzed. The tests showed that the silkworm manure fertilization did not affect the lignocellulosic structures content in Henola cultivar. Small variation in the content of ligno-cellulose after fertilization may prove that this cultivar is a seed-type hemp (Tab. 4).

The ANOVA results showed that there was significant difference in mean total length between repetitions $F=134.72, p<0.001, \Delta \eta^{2}=0.62$. In order to verify between which particular pairs of repetitions a significant difference has occurred, post hoc tests with Bonferroni correction were run. The analysis also showed that there was significant difference in mean total length between level of fertilization $F=4.75, p<0.01$, $\Delta \eta^{2}=0.05$. For this effect, the post hoc tests with Bonferroni correction were applied as well. Repetition had a greater influence on mean total length then level of fertilization, level of the former allowed to explain $62 \%$ of variance of mean total length (Tab. 5).

The results of post hoc tests revealed that there were significant differences in mean total length in each compared repetitions (Tab. 6-8). The highest mean total length was observed in R2 $(M=127.31 ; S D=16.23)$, moderate value in R3 $(M=83.49, S D=24.43)$ and the lowest mean total length was observed in $\mathrm{R} 1(M=71.41$, $S D=8.40$ ). In the case of fertilization, there was significant difference between fertilizing with 15 tons $(M=95.15, S D=30.96)$ and the non fertilization variant $(M=85.71, S D=25.30)$ (Fig. 1$)$.

The ANOVA results showed that there was significant difference in mean technical length between repetitions $F=172.95, p<0.001$, $\Delta \eta^{2}=0.68$. In order to verify between which

Table 1. The medium values of hemp measures $(\mathrm{n}=24$, in $\mathrm{cm})$.

\begin{tabular}{|c|c|c|c|c|c|}
\hline \multirow{2}{*}{ Repetition } & $\begin{array}{c}\text { Dose of } \\
\text { fertilization }\end{array}$ & Total length & Technical length & Panicles length & Diameter \\
\hline \multirow{3}{*}{ R1 } & control & 68.25 & 49.65 & 12.92 & 0.224 \\
\cline { 2 - 6 } & 15 t/ha & 76.92 & 62.67 & 14.11 & 0.284 \\
\cline { 2 - 6 } & 30 t/ha & 68.30 & 53.34 & 14.96 & 0.315 \\
\hline \multirow{4}{*}{ R2 } & control & 120.80 & 99.80 & 21.00 & 0.353 \\
\cline { 2 - 6 } & 15 t/ha & 134.13 & 111.46 & 22.66 & 0.410 \\
\cline { 2 - 6 } & 30 t/ha & 127.00 & 108.13 & 13.16 & 0.420 \\
\hline \multirow{3}{*}{ R3 } & control & 82.81 & 64.96 & 18.10 & 0.202 \\
\cline { 2 - 6 } & 15 t/ha & 87.80 & 69.70 & 24.95 & 0.420 \\
\cline { 2 - 6 } & 30 t/ha & 86.98 & 61.11 & & 0.402 \\
\hline
\end{tabular}

Table 2. The periods of plants growth and development, including intensive life processes from sowing to harvesting.

\begin{tabular}{|c|c|c|c|c|c|c|}
\hline & Sowing time & Emergence period & Flowering period & Ripening period & Harvesting time & $\begin{array}{c}\text { Time of vegetation } \\
\text { (days) }\end{array}$ \\
\hline R1 & 15.05 & 23.05 & $27.06-2.08$ & $1.08-30.08$ & 30.08 & 107 \\
\hline R2 & 02.05 & $9-15.05$ & $25.06-1.08$ & $30.07-1.09$ & 01.09 & 122 \\
\hline R3 & 13.05 & 20.05 & $25.06-1.08$ & $28.07-2.09$ & 02.09 & 112 \\
\hline
\end{tabular}


particular pairs of repetitions a significant difference has occurred,, the post hoc tests with Bonferroni correction were run. The analysis also showed that there was significant difference in mean technical length between dose of fertilization $F=6.37, p<0.01, \Delta \eta^{2}=0.07$. For this effect, the post hoc tests with Bonferroni correction were applied. Repetition had a greater influence on mean technical length then dose of fertilization, level of the former allowed to explain $68 \%$ of variance of mean technical length (Tab. 9).

The results of post hoc tests revealed that there were significant differences in mean technical length in each compared pair of repetitions
(Tab. 10-12). The highest mean technical length was observed in R2 $(M=106.47 ; S D=14.59)$, moderate value in R3 $(M=65.34, S D=18.80)$ and the lowest mean total length was observed in $\mathrm{R} 1(M=55.73, S D=8.66)$. In the case of fertilization, there was significant difference between fertilizing with $15 \mathrm{t} / \mathrm{ha}(M=77.46, S D=25.08)$ and control variant $(M=68.93, S D=26.46)$ (Fig. 2$)$.

The ANOVA results showed that there was significant difference in mean length of panicle between repetitions $\mathrm{F}=4.21, \mathrm{p}<0.05, \Delta \eta^{2}=0.05$ (Tab. 13). In order to verify between which particular pairs of repetitions a significant difference has occurred, post hoc tests with Bonferroni

Table 3. The results of analyses pertaining to the chemical composition of excreta.

\begin{tabular}{|c|c|c|c|c|c|c|c|c|c|c|c|}
\hline \multicolumn{2}{|c|}{} & \multicolumn{9}{c|}{$\%$ FM } & \multicolumn{4}{c|}{$\mathrm{mg} / \mathrm{kg} \mathrm{DM}$} \\
\hline $\mathrm{pH}$ & $\mathrm{DM} \%$ & $\mathrm{~N}$ & $\mathrm{P}_{2} \mathrm{O}_{5}$ & $\mathrm{~K}_{2} \mathrm{O}$ & $\mathrm{CaO}$ & $\mathrm{MgO}$ & $\mathrm{Cu}$ & $\mathrm{Mn}$ & $\mathrm{Zn}$ & $\mathrm{Cd}$ & $\mathrm{Pb}$ \\
\hline 7.25 & 86.82 & 2.56 & 1.0 & 2.7 & 3.24 & 0.56 & 8.64 & 67.4 & 15.6 & $<0.138$ & $<1.20$ \\
\hline
\end{tabular}

Table 4. The results of analyses pertaining to the chemical composition of hemp biomass (in \%).

\begin{tabular}{|c|l|c|c|c|c|c|c|c|}
\hline \multicolumn{2}{|c|}{ Dose } & Extractables & Cellulose & Lignin & Pentosans & Holocellulose & Hemicelulose & Minerals \\
\hline \multirow{4}{*}{ R1 } & control & 6.16 & 47.68 & 14.58 & 17.47 & 79.22 & 31.54 & 5.02 \\
\cline { 2 - 9 } & 15 t/ha & 5.40 & 47.64 & 14.18 & 19.78 & 79.54 & 31.90 & 5.01 \\
\cline { 2 - 9 } & 30 t/ha & 5.60 & 46.43 & 14.79 & 19.31 & 79.04 & 32.61 & 4.38 \\
\hline \multirow{4}{*}{ R2 } & control & 3.97 & 48.48 & 14.50 & 19.22 & 77.78 & 29.30 & 4.68 \\
\cline { 2 - 9 } & 15 t/ha & 4.00 & 50.72 & 15.43 & 16.54 & 76.31 & 25.59 & 4.01 \\
\cline { 2 - 9 } & 30 t/ha & 3.51 & 49.10 & 15.40 & 17.11 & 77.41 & 28.31 & 3.96 \\
\hline \multirow{4}{*}{ R3 } & control & 5.59 & 47.42 & 13.85 & 18.50 & 76.44 & 29.02 & 5.17 \\
\cline { 2 - 9 } & 15 t/ha & 6.38 & 46.38 & 14.92 & 18.74 & 76.83 & 30.45 & 5.64 \\
\cline { 2 - 9 } & 30 t/ha & 8.59 & 46.37 & 15.34 & 18.17 & 76.24 & 29.87 & 5.23 \\
\hline
\end{tabular}

Table 5. Results of ANOVA for effects of repetition and fertilization on mean total length.

\begin{tabular}{|c|c|c|c|c|}
\hline Dependant Variable & Effect & $\mathrm{F}$ & $\mathrm{p}$ & $\Delta \eta^{2}$ \\
\hline \multirow{2}{*}{ Mean total length } & Repetitions & 134.72 & $<0.001$ & 0.62 \\
\hline & Fertilization & 4.75 & $<0.01$ & 0.05 \\
\hline
\end{tabular}

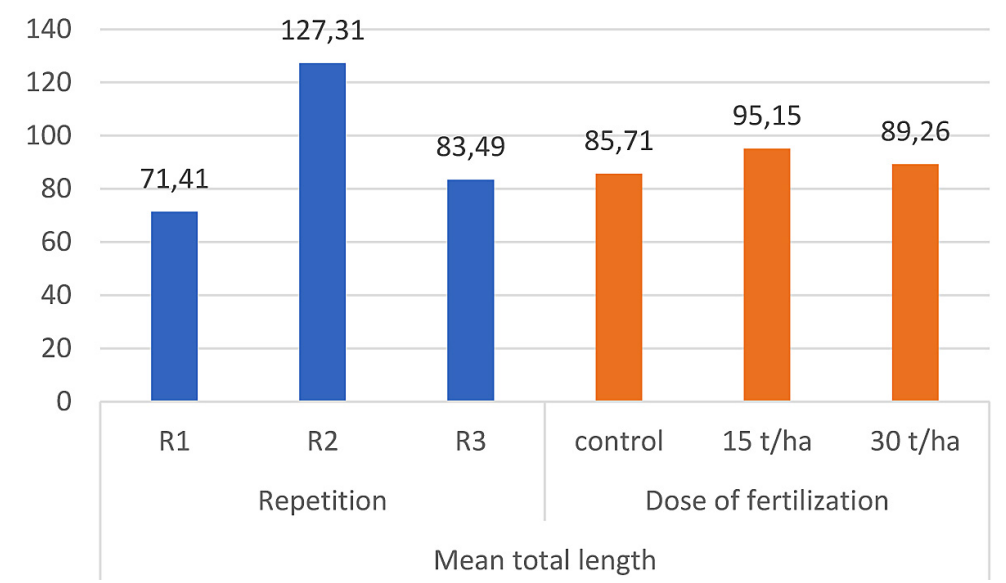

Figure 1. Results of post hoc tests for influence of repetition and fertilization dose on mean total length (in $\mathrm{cm}$ ). 
Table 6. Descriptive statistics for mean total length broken down into repetitions and fertilization.

\begin{tabular}{|c|c|c|c|c|c|}
\hline Dependant Variables & Effect & Categories & $\mathrm{N}$ & $\mathrm{M}$ & $\mathrm{SD}$ \\
\hline \multirow{4}{*}{ Mean total length } & \multirow{3}{*}{ Repetition } & $\mathrm{R} 1$ & 66 & 71.41 & 8.40 \\
\cline { 3 - 6 } & & $\mathrm{R} 2$ & 45 & 127.31 & 16.23 \\
\cline { 3 - 6 } & \multirow{3}{*}{ Fertilization } & $\mathrm{R} 3$ & 68 & 83.49 & 24.43 \\
\cline { 3 - 6 } & & control & 58 & 85.71 & 25.30 \\
\cline { 3 - 6 } & & 15 t/ha & 62 & 95.15 & 30.96 \\
\cline { 3 - 6 } & & 30 t/ha & 89.26 & 28.56 \\
\hline
\end{tabular}

Table 7. Results of post hoc test for influence of fertilization doses on mean total length.

\begin{tabular}{|c|c|c|c|c|c|}
\hline \multicolumn{2}{|c|}{ Compared pair } & Mean Difference & SE & $\mathrm{t}$ & $\mathrm{p}$ \\
\hline \multirow{2}{*}{ R1 } & R2 & -56.16 & 3.40 & -16.52 & $<0.001$ \\
\cline { 2 - 6 } & R3 & -12.58 & 3.05 & -4.13 & $<0.001$ \\
\hline R2 & R3 & 43.59 & 3.38 & 12.91 & $<0.001$ \\
\hline
\end{tabular}

Table 8. Results of post hoc test for influence of repetition on mean total length.

\begin{tabular}{|c|c|c|c|c|c|}
\hline \multicolumn{2}{|c|}{ Compared pair } & Mean Difference & $\mathrm{SE}$ & $\mathrm{t}$ & $\mathrm{p}$ \\
\hline \multirow{2}{*}{ control } & $15 \mathrm{t} / \mathrm{ha}$ & -10.73 & 3.31 & -3.25 & $<0.01$ \\
\cline { 2 - 7 } & $30 \mathrm{t} / \mathrm{ha}$ & -4.80 & 3.27 & -1.47 & 0.43 \\
\hline $15 \mathrm{t} / \mathrm{ha}$ & $30 \mathrm{t} / \mathrm{ha}$ & 5.93 & 3.26 & 1.82 & 0.21 \\
\hline
\end{tabular}

Table 9. Results of ANOVA for effects of repetition and fertilization on mean technical length.

\begin{tabular}{|c|c|c|c|c|}
\hline Dependant Variable & Effect & $\mathrm{F}$ & $\mathrm{p}$ & $\Delta \eta^{2}$ \\
\hline \multirow{2}{*}{ Mean technical length } & Repetition & 172.95 & $<0.001$ & 0.68 \\
\cline { 2 - 5 } & Fertilization & 6.37 & $<0.01$ & 0.07 \\
\hline
\end{tabular}

Table 10. Descriptive statistics for mean technical length broken down into repetitions and dose of fertilization.

\begin{tabular}{|c|c|c|c|c|c|}
\hline Dependant Variables & Effect & Categories & $\mathrm{N}$ & $\mathrm{M}$ & $\mathrm{SD}$ \\
\hline \multirow{4}{*}{ Mean technical length } & \multirow{3}{*}{ Repetition } & $\mathrm{R} 1$ & 66 & 55.73 & 8.66 \\
\cline { 3 - 6 } & & $\mathrm{R} 2$ & 45 & 106.47 & 14.59 \\
\cline { 3 - 6 } & \multirow{3}{*}{ Fertilization } & $\mathrm{R} 3$ & 68 & 65.34 & 18.80 \\
\cline { 3 - 7 } & & Control & 58 & 68.90 & 23.00 \\
\cline { 3 - 7 } & & $15 \mathrm{t} / \mathrm{ha}$ & 59 & 77.46 & 25.08 \\
\cline { 3 - 6 } & & $30 \mathrm{t} / \mathrm{ha}$ & 62 & 70.10 & 26.46 \\
\hline
\end{tabular}

Table 11. Results of post hoc test for the influence of repetitions on mean technical length.

\begin{tabular}{|c|c|c|c|c|c|}
\hline \multicolumn{2}{|c|}{ Compared pair } & Mean Difference & SE & $\mathrm{t}$ & $\mathrm{p}$ \\
\hline \multirow{2}{*}{ R1 } & R2 & -56.16 & 3.40 & -16.52 & $<0.001$ \\
\cline { 2 - 6 } & R3 & -12.58 & 3.05 & -4.13 & $<0.001$ \\
\hline R2 & R3 & 43.59 & 3.38 & 12.91 & $<0.001$ \\
\hline
\end{tabular}

Table 12. Results of post hoc test for the influence of fertilization dose on mean technical length.

\begin{tabular}{|c|c|c|c|c|c|}
\hline \multicolumn{2}{|c|}{ Compared pair } & Mean Difference & SE & $\mathrm{t}$ & $\mathrm{p}$ \\
\hline \multirow{2}{*}{ control } & $15 \mathrm{t} / \mathrm{ha}$ & -10.73 & 3.31 & -3.25 & $<0.01$ \\
\cline { 2 - 7 } & $30 \mathrm{t} / \mathrm{ha}$ & -4.80 & 3.27 & -1.47 & 0.43 \\
\hline $15 \mathrm{t} / \mathrm{ha}$ & $30 \mathrm{t} / \mathrm{ha}$ & 5.93 & 3.26 & 1.82 & 0.21 \\
\hline
\end{tabular}




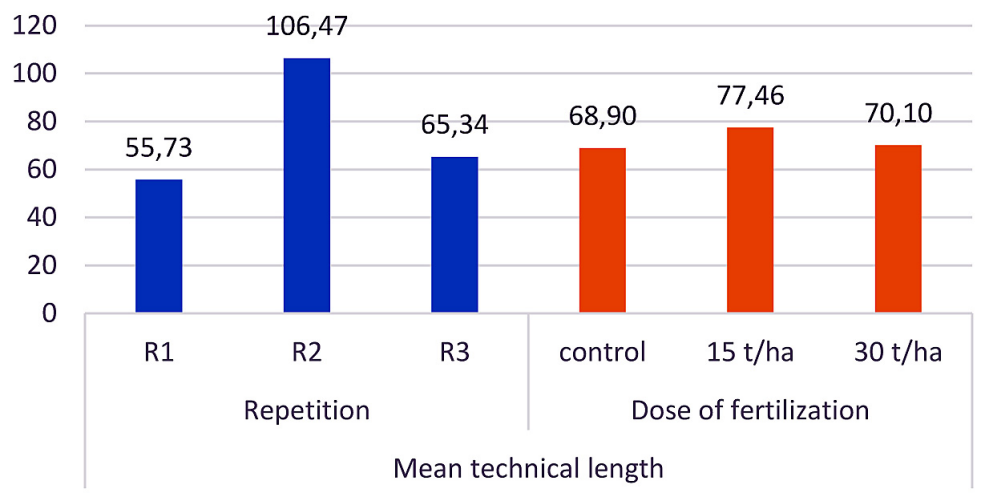

Figure 2. Results of post hoc tests for the influence of repetition and fertilization dose on mean technical length (in $\mathrm{cm}$ ).

Table 13. Results of ANOVA for effects of repetition and dose of fertilization on mean length of panicle.

\begin{tabular}{|c|c|c|c|c|}
\hline Dependant Variable & Effect & $\mathrm{F}$ & $\mathrm{p}$ & $\Delta \eta^{2}$ \\
\hline \multirow{2}{*}{ Mean length of panicle } & Repetition & 4.21 & $<0.05$ & 0.05 \\
\cline { 2 - 5 } & Fertilization & 0.49 & 0.61 & 0.01 \\
\hline
\end{tabular}

correction were run. The analysis also showed that there was no significant difference in mean length of panicle between dose of fertilization $\mathrm{F}=0.49, \mathrm{p}<0.61, \Delta \eta^{2}=0.01$. Repetition allowed to explain $5 \%$ of variance of mean length of panicle (Fig. 3).

The results of the post hoc tests revealed that there were significant differences in mean panicle length between R1 and R2. Mean length of panicle was greater in the latter period of time $(\mathrm{M}$ $=20.84, \mathrm{SD}=8.31)$ then in the former $(\mathrm{M}=15.68$, $\mathrm{SD}=5.09)($ Tab. 14-16).

The ANOVA results showed that there was significant difference in mean diameter of technical length between repetitions $F=8,46, p<0.001$, $\Delta \eta^{2}=0.09$ (Tab. 17). In order to verify between which particular pairs of repetition a significant difference has occurred, post hoc tests with
Bonferroni correction were run. The analysis also showed that there was a significant difference in mean diameter of technical length between dose of fertilization $F=5.07, p<0.01, \Delta \eta^{2}=0.06$. For this effect, post hoc tests with Bonferroni correction were applied as well. Repetition had a greater influence on mean diameter of technical length, including level of the former allowed to explain $9 \%$ of variance of overall crop (Fig. 4).

The results of post hoc tests revealed that there were significant differences in mean diameter of technical length between R2 and other repetitions. In R2, the value of mean diameter of technical length was significantly higher $(M=4.50$, $S D=3.93)$ then in others periods of time (R1: $M=2.90, S D=0.48 ; \mathrm{R} 3: M=3.07, S D=1.55$ ) (Tab. 18-20). In the case of fertilization, there was significant difference between control and

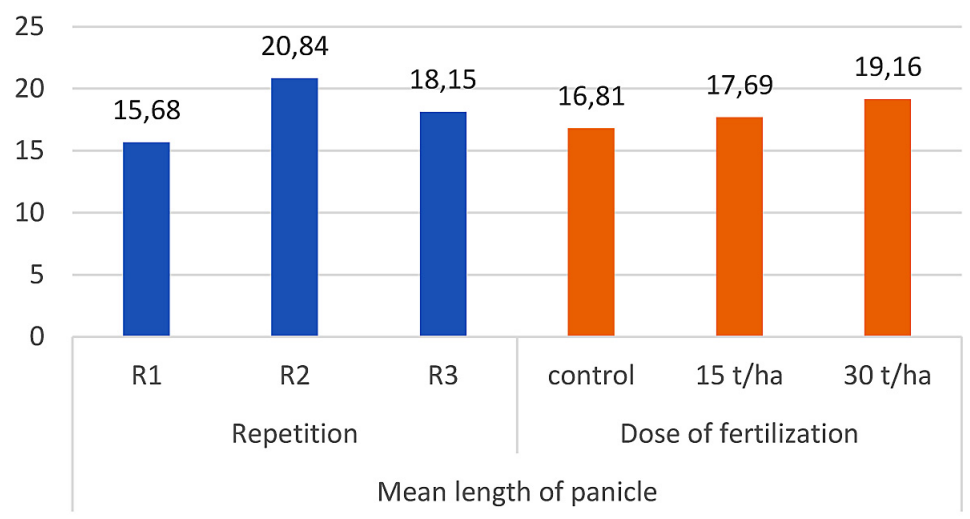

Figure 3. Results of post hoc tests for influence of repetition and fertilization dose on mean panicle length (in $\mathrm{cm}$ ). 
Table 14. Descriptive statistics for mean length of panicle broken down into repetitions and dose of fertilization.

\begin{tabular}{|c|c|c|c|c|c|}
\hline Dependant Variables & Effect & Categories & $\mathrm{N}$ & $\mathrm{M}$ & $\mathrm{SD}$ \\
\hline \multirow{4}{*}{$\begin{array}{c}\text { Mean length of } \\
\text { panicle }\end{array}$} & \multirow{3}{*}{ Repetition } & $\mathrm{R} 1$ & 66 & 15.68 & 5.09 \\
\cline { 3 - 6 } & & $\mathrm{R} 2$ & 45 & 20.84 & 8.31 \\
\cline { 3 - 6 } & \multirow{3}{*}{ Fertilization } & $\mathrm{R} 3$ & 68 & 18.15 & 11.90 \\
\cline { 3 - 6 } & & $\mathrm{control}$ & 58 & 16.81 & 7.12 \\
\cline { 3 - 6 } & & $15 \mathrm{t} / \mathrm{ha}$ & 59 & 17.69 & 8.86 \\
\cline { 3 - 6 } & $30 \mathrm{t} / \mathrm{ha}$ & 62 & 19.16 & 10.95 \\
\hline
\end{tabular}

Table 15. Results of post hoc test for influence of repetition on mean length of panicle.

\begin{tabular}{|c|c|c|c|c|c|}
\hline \multicolumn{2}{|c|}{ Compared pair } & Mean Difference & SE & $\mathrm{t}$ & $\mathrm{p}$ \\
\hline \multirow{2}{*}{ R1 } & R2 & -4.99 & 1.67 & -2.99 & $<0.05$ \\
\cline { 2 - 6 } & R3 & -2.29 & 1.49 & -1.53 & 0.38 \\
\hline R2 & R3 & 2.70 & 1.66 & 1.63 & 0.32 \\
\hline
\end{tabular}

Table 16. Results of post hoc test for influence of fertilization dose on mean panicle length.

\begin{tabular}{|c|c|c|c|c|c|}
\hline \multicolumn{2}{|c|}{ Compared pair } & Mean Difference & SE & $\mathrm{t}$ & $\mathrm{p}$ \\
\hline \multirow{2}{*}{ control } & $15 \mathrm{t} / \mathrm{ha}$ & -0.90 & 1.62 & -0.55 & 1.00 \\
\cline { 2 - 7 } & $30 \mathrm{t} / \mathrm{ha}$ & -1.62 & 1.61 & -1.01 & 0.94 \\
\hline \multirow{2}{*}{$15 \mathrm{t} / \mathrm{ha}$} & $30 \mathrm{t} / \mathrm{ha}$ & -0.73 & 1.60 & -0.46 & 1.00 \\
\hline
\end{tabular}

Table 17. Results of ANOVA for effects of repetition and dose of fertilization on mean diameter of technical length.

\begin{tabular}{|c|c|c|c|}
\hline Dependant Variable & Effect & $\mathrm{F}$ & $\mathrm{p}$ \\
\hline \multirow{2}{*}{ Mean diameter of technical length } & Repetition & 8.46 & $<0.001$ \\
\cline { 2 - 5 } & Fertilization & 5.07 & $<0.01$ \\
\hline
\end{tabular}

hemp fertilized. Higher mean diameter of technical length was observed in the latter situation (30 t/ha: $M=3.71, S D=1.04 ; 15$ t/ha: $M=3.73$, $S D=3.67)$ then in former $(M=2.61, S D=0.89)$.

Numerous studies referred to the mineral fertilization of hemp plantations. It has been proven that hemp responds well to additional $\mathrm{N}$ fertilizer resulting in increased plant biomass and seed production [Vera et al. 2010]. The most popular oiltype cultivar Finola gave $27 \%$ higher seed yield after an additional unit of $\mathrm{N}$ fertilizer $(198 \mathrm{~kg} / \mathrm{ha}$ of $\mathrm{N}$ ) than the optimal rate [Aubin et al. 2015].

The effect of sowing density (20,40 and $60 \mathrm{~kg} / \mathrm{ha}$ ) on the height and quality of the Henola

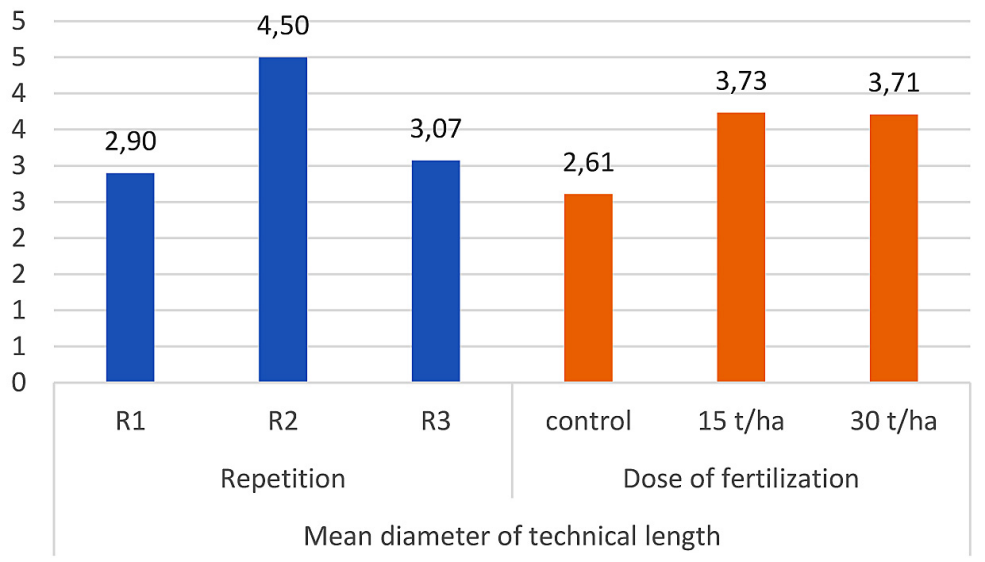

Figure 4. Results of post hoc tests for influence of repetition and fertilization dose on mean diameter of technical length (in $\mathrm{mm}$ ). 
Table 18. Descriptive statistics for mean diameter of technical length broken down into repetition and fertilization dose.

\begin{tabular}{|c|c|c|c|c|c|}
\hline Dependant Variables & Effect & Categories & $\mathrm{N}$ & $M$ & SD \\
\hline \multirow{6}{*}{$\begin{array}{l}\text { Mean diameter of technical } \\
\text { length }\end{array}$} & \multirow{3}{*}{ Repetition } & $\mathrm{R} 1$ & 61 & 2.90 & 0.48 \\
\hline & & $\mathrm{R} 2$ & 45 & 4.50 & 3.93 \\
\hline & & R3 & 68 & 3.07 & 1.55 \\
\hline & \multirow{3}{*}{ Fertilization } & control & 53 & 2.61 & 0.89 \\
\hline & & $15 \mathrm{t} / \mathrm{ha}$ & 59 & 3.73 & 3.67 \\
\hline & & $30 \mathrm{t} / \mathrm{ha}$ & 62 & 3.71 & 1.04 \\
\hline
\end{tabular}

Table 19. Results of post hoc test for influence of repetition on mean diameter of technical length.

\begin{tabular}{|c|c|c|c|c|c|}
\hline \multicolumn{2}{|c|}{ Compared pair } & Mean Difference & SE & $\mathrm{t}$ & $\mathrm{p}$ \\
\hline \multirow{2}{*}{ R1 } & R2 & -1.64 & 0.43 & -3.84 & $<0.001$ \\
\cline { 2 - 6 } & R3 & -0.22 & 0.39 & -0.57 & 1.00 \\
\hline R2 & R3 & 1.42 & 0.41 & 3.43 & $<0.01$ \\
\hline
\end{tabular}

Table 20. Results of post hoc test for influence of fertilization on mean diameter of technical length.

\begin{tabular}{|c|c|c|c|c|c|}
\hline \multicolumn{2}{|c|}{ Compared pair } & Mean Difference & $\mathrm{SE}$ & $\mathrm{t}$ & $\mathrm{p}$ \\
\hline \multirow{2}{*}{ control } & $15 \mathrm{t} / \mathrm{ha}$ & -1.25 & 0.42 & -3.01 & $<0.05$ \\
\cline { 2 - 7 } & $30 \mathrm{t} / \mathrm{ha}$ & -1.03 & 0.41 & -2.50 & $<0.05$ \\
\hline $15 \mathrm{t} / \mathrm{ha}$ & $30 \mathrm{t} / \mathrm{ha}$ & 0.22 & 0.40 & 0.55 & 1.00 \\
\hline
\end{tabular}

seed yield as well as the impact of mineral fertilization (in $\mathrm{kg} / \mathrm{ha}$ ): $40 \mathrm{~N}, 30 \mathrm{P}_{2} \mathrm{O}_{5}$ and $80 \mathrm{~K}_{2}$ $\mathrm{O}$ were investigated. The air dry matter biomass yield of Henola ranged from $145 \mathrm{dt} /$ ha with $\mathrm{N}$ fertilization of $20 \mathrm{~kg} / \mathrm{ha}$ to $180 \mathrm{dt} / \mathrm{ha}$ with $60 \mathrm{~kg} / \mathrm{ha}$ of nitrogen [Burczyk and Oleszak 2016].

The present study also recorded the higher biomass yield after fertilization with silkworm manure. The mean total length increased by $111 \%$ and the mean technical length improved by $112 \%$ in 15t/ha of manure dose, in comparison with the control. The highest length of hemp was recorded in $\mathrm{R} 2$ and it is believed that this is a result of a vegetation period in the second year of study that was 10 days longer. On the other hand, the panicles were longer by $114 \%$ after $30 \mathrm{t} / \mathrm{ha}$ of manure dose, in comparison with the control. Moreover, the mean diameter of hemp was higher by $142 \%$ after 30 t/ha dose of breeding waste, in comparison with the control.

\section{CONCLUSION}

The application of silkworm manure to hemp crop increases the growth and yield of plants. The fertilization in dose $15 \mathrm{t} /$ ha of breeding waste may increase the biomass yield by producing higher plants. In turn, $30 \mathrm{t} / \mathrm{ha}$ dose of silkworm manure may improve the seed production from larger panicles. It is also recorded that longer vegetation period plays an important role in yield improving. Furthermore, effective utilization of sericulture waste minimizes the environmental pollution and is a good alternative helping to restrict the use of inorganic fertilizers. Hence, the present investigation was carried out with the objective of assessing the effect of silkworm manure on yields of Cannabis L.

\section{Acknowledgements}

This paper was prepared as a result of the realization of the project entitled: "Maintaining a unique Polish breeding of the mulberry silkworms varieties" financed by the Polish Ministry of Science and Higher Education (contract number 205710/E-198/SPUB/2015/2).

\section{REFERENCES}

1. Aubin, M-P., Seguin, P., Vanasse, A., Tremblay, G.F., Mustafa, A.F., Charron, J-B., 2015. Industrial hemp response to nitrogen, phosphorus, and potassium fertilization. Crop, Forage, Turfgrass Manage 12,1-10, DOI: $10.2134 / \mathrm{cftm} 2015.0159$.

2. Burczyk H. 2012. The annual plants cultivated for biomass supplying to professional energy generation. 
Problemy Inżynierii Rolniczej, 20, 59-68 (in Polish).

3. Burczyk H., Oleszak, G. 2016. Oilseed hemp (Cannabis sativa L. var. oleifera) grown for seeds, oil and biogas. Problemy Inżynierii Rolniczej, 24, 109-116 (in Polish).

4. Chen X.P., Xie Y.J., Luo G.E., Shi W.Y. 2011. Silkworm excrement organic fertilizer: its nutrient properties and application effect. Chinese Journal of Applied Ecology, 22(7), 1803-1809.

5. Colizzi M., Murray R. 2018. Cannabis and psychosis: what do we know and what should we do? The British Journal of Psychiatry, 212, 195-196.

6. Dobre P., Nicolae F., Matei F. 2014. Main factors affecting biogas production - an overview. Rom. Biotech. Lett, 19, 9283-96.

7. Farhat I.Q., Malik M.A., Banday M.T., Bhat S.A., Sharma R.K. 2015. Possibilities for utilization of waste products of sericultural industry in animal/ poultry feeds. International Journal of Advanced Biological Research, 5(4), 363-365.

8. Gulluni N., Re T., Loiacono I., Lanzo G., Gori L., Macchi C., Epifani F., Bragazz N., Firenzuoli F. 2018. Cannabis Essential Oil: a preliminary study for the evaluation of the brain effects. EvidenceBased Complementary and Alternative Medicine, article ID: 1709182, 11 pages.

9. Li Ping, Fu HongTing, Zhang FaBao, Pang YuWan, Huang QiaoYi, Tang ShuanHu. 2015. Effects of silkworm excrement-derived organic fertilizer on yield and quality of crops and soil property. Journal of Southern Agriculture, 46(7), 1195-1199.

10. Łochyńska M., Frankowski J. 2018. The biogas production potential from silkworm waste. Waste Management, 79, 564-570.
11. Mannucci C., Navarra M., Calapai F., Spagnolo E.V., Busardò F.P., Cas R.D., Ippolito F.M., Calapai G. 2017. Neurological aspects of medical use of cannabidiol. CNS \& Neurological Disorders-Drug Targets (Formerly Current Drug Targets-CNS \& Neurological Disorders), 16, 541-553.

12. Sawpan M.A., Pickering K.L., Fernyhough A. 2011. Improvement of mechanical performance of industrial hemp fibre reinforced polylactide biocomposites. Composites Part A: Applied Science and Manufacturing, 42, 310-319.

13. Rehman M.S.U., Rashid N., Saif A., Mahmood T., Han J.I. 2013. Potential of bioenergy production from industrial hemp (Cannabis sativa): Pakistan perspective. Renewable and sustainable energy reviews, 18, 154-164.

14. Wang X., Zhang J., Yao L., Pang L., Tang T. 2016. The status of quantitative analysis and utilization of various components in silkworm excrement. Science of Sericulture, 42(5), 918-925 (in Chinese).

15. Vera C.L., Malhi S.S., Phelps S.M., May W.E., Johnson E.A. 2010. N, P and S fertilization on industrial hemp in Saskatchewan. Can. J. Plant Sci., 90, 179-184.

16. Yaman H. 2016. Recycling feces of silkworm by feeding cows. International Presidential School, Dushanbe, 1-17.

17. Yang, Q., Li, L., Xing, D., Li, Q., Xiao, Y., Ye, M., Liao, S., 2016. Influence of adding silkworm excrement organic fertilizer in mulberry field on soil enzyme activity and mulberry leaf yield and quality. Science of Sericulture, 42(6), 968-972, ISSN 0257-4799 (in Chinese). 